\title{
Land Tenure Distribution And Well Being Of Women In Nigeria
}

\author{
Abdulazeez Hakeem Omilola *, Abdulfatai Salawu Oyebode **, David Ayock Ishaya ** \\ * Department of Estate Management and Valuation, Waziri Umaru Federal Polytechnic, Birnin-Kebbi, Nigeria \\ *** Department of Estate Management and Valuation, Hussaini Adamu Federal Polytechnic, Kazaure, Nigeria.
}

DOI: 10.29322/IJSRP.11.12.2021.p12048

http://dx.doi.org/10.29322/IJSRP.11.12.2021.p12048

\begin{abstract}
The land use act of 1978 is the linchpin for all land related issues in Nigeria, land also has a strong and positive correlation with economic activities in a country. Nigeria being the largest economy in Africa and the 26th largest economy in the world is still grappling issues of gender equality and empowerment. The aim of this research is to explore the nexus between land tenure distribution and the wellbeing of women in Nigeria. Using a cross sectional data of the living standards measurement study-integrated surveys on agriculture, general household survey panel for 2015-2016, the national representative survey of 5,000 households, representing the geopolitical zones consisting of 1907 women of which 558 are in the urban area and 1349 are in the rural area, which contained data on the marital status, years of education, land tenure distribution, health problems, labor activities and average household size. An econometric model was developed to determine the income activities that relates to the land tenure distribution of the women, hence their wellbeing. The results show that land tenure type is positively correlated with the wellbeing of the women, also labor activity, years of education and the type of illness are all positively correlated to the wellbeing of women in Nigeria. The paper recommended that the land use act of 1978 should be reviewed and reform to capture the present day reality of vulnerable women to owned land in Nigeria, whether married, single, separated or widowed.
\end{abstract}

Index Terms- Distribution, Household, Land tenure, Wellbeing, Women

\section{INTRODUCTION}

$\mathrm{L}$ and policies often address two main complementary issues. The first question concerns the strengthening of land rights and tenure security historically weak in most developing countries (Place, 2009). In the recent years, several countries in Africa initiated land reforms with the aim to formalize property rights and improve tenure security (Deininger \& Feder, 2009). The rationale behind these increased interests in land reforms is that improving and securing household access to land provide sufficient incentives to farm investment and productivity growth (Abdulai, Owusu \& Goetz, 2011). This hypothesis has been widely explored theoretically and tested empirically. While there are conflicting findings, the body of evidence tends to support the argument that secure access to land enhances farm investment and productivity (Deininger \& Feder, 2009). Individuals' investments in a particular plot might in turn influence their claims over that piece of land.

As a result of a general concern about the status and opportunities of women in developing countries, the relationships between the process of development and gender inequality have been analyzed from the legal, social, economic, political, and moral dimensions, using the approaches and toolkits of various disciplines(Fox, 2015), the issue of how to ensure that economic development expands choices and opportunities for women, especially poorer and vulnerable women, is now part of ma instream economic development theory and policy analysis (Afridi, Mukhopadhyay \& Sahoo, 2011).Hence the need for the study.

This paper takes one step further and provides an empirical framework that enables us first to test whether improving the land tenure of women will improve their wellbeing, second, it allows us to test whether the negative correlation between gender-based financial exclusion and the economic growth rate can be mediated through land tenure improvement. The aim of this paper is to show that securing the land tenure of women will improve their wellbeing and hence reduce poverty. The paper is structured as follows. In the next section, review of related literature, empirical model, followed by, data and sample, empirical analysis and results. Finally Conclusion and policy implications.

\section{REVIEW OF RELATED LITERATURE}

\subsection{Wellbeing of women}

Extensive research has been carried out in developed countries in understanding how important relative income and consumption are for individual wellbeing and behavior, compared to their absolute income. However, there are scarce empirical evidences on the land tenure distribution and well-being of women in Nigeria. In addition, the concerns about status as an important issue for the well-being of people in richer or developed countries than in poor countries has only very recently been revised and empirically tested using both subjective well-being data, and objective and subjective approaches (Akay \& Martinsson, 2011). Securing women's rights to land has beneficial welfare impacts by reducing vulnerability when economic shocks occur, or after divorce or widowhood. These beneficial welfare effects do not necessarily arise from simply improving household's access to land since intra-household distribution is not always equitable 
(Lastarria-Cornhiel, Julia, Ruth \& Agnes, 2011). Indicators of women's well-being and autonomy include a host of measures such as their agricultural productivity and earnings, self-esteem, the respect they garner from other family members, employment, educational attainment, mobility outside of the home, and decision-making power.

Furthermore, social deprivation or social relative concerns refers to deprivation in terms of the inability to fulfill the exceptions and pressures of family, neighbors and tutors, say school teachers, and the failure to participate in customary community events (Townsend, 1997). Its best captured by measures of social capital such as trust and cooperative relations between individual who share social identity e.g. Ethnicity and connections with others of comparative status and power (Kawachi et al., 2004). It points to power and prestige dimensions of relative deprivation. In this paper social wellbeing is Relative income based on assertions by Akay and Martinsson (2011)

\subsection{Land tenure security and investment}

Tenure insecurity is a bane to smallholder agricultural planning. The association between tenure security and land investments has been addressed in a number of theoretical works (Ghatak \& Besley, 2010). These studies argue that greater tenure security can enhance land related investments in the following ways; first, a lower probability of expropriation is expected to increase smallholders' returns on land investments. Second, if tenure security has been strengthened, through for example, the introduction of titles, credit constraints may be relaxed because land gains collateral value (Braselle, Gaspart \& Platteau, 2002).

If land is easier to collateralize, it reduces asymmetric information and leads formal lending institutions to lower the interest rates making it more attractive for farmers to invest in land. Lastly, if tenure security is enhanced through formal property rights and a land market exists where smallholders can convert land to liquid assets through sales or rent, farmers may have a higher incentive to invest in land so that they may yield higher returns (Fenske, 2011). Out of these three channels, it is the former that has received the most attention from development scholars that have analysed how several factors such as political connectivity, inheritance customs and land reform programs influence tenure security and investments (Banerjee et al., 2002). For instance, researchers have found out that, there is a positive association between tenure security, fallow, agricultural productivity and soil conservation on one hand and also that there is little support for the role of tenure security in enhancing productivity.

Fenske (2011) provides several reasons for why a mismatch between the theoretical and empirical literature exists. For instance, he argues that customary systems may already be secure with a very small risk of expropriation. If customary rights are secure smallholders will invest in their parcels even if they do not have formal title. This means that studies that use titling programs to signify the highest form of tenure security may not find an effect of increased as smallholders may already tenure secure despite not having title to their land. Moreover, Fenske (2011) posits that smallholders' may continue to engage in investments even if tenure insecurity is high and that the time horizon of the investment matters. If smallholders perceive that the risk of eviction or expropriation is high, smallholders will invest in short term strategies such as intensified input use to increase yield rather than in the cultivation of perennials that are more time consuming.

In addition, if investment is endogenous and can also strengthen land rights, which is the case for tree planting in West Africa, it is not clear whether investments are undertaken to secure tenure or if they are an outcome of greater tenure security (Brasselle, et al., 2002). Another factor that is likely to have driven the inconsistency in empirical findings is the small sample sizes with limited external validity (Deininger \& Jin, 2006). Many of the earlier studies that have shaped the literature where conducted on samples of less than 300 households.

\section{METHODOLOGY}

\subsection{Empirical Model}

We initially posit the log-linear version of a constant coefficient augmented Cobb-Douglas agricultural production function at the farm household level:

$y_{i}=\alpha_{0}+z_{i} \alpha+X_{i} \beta+u_{i}$

In (1) a farm household $i$ transforms a vector of inputs land, labor, fertilizer and equipment into the output, $y-$ the aggregate of the quantity harvested of each crop. Land is measured at the household level by aggregating individual plot sizes. In (1), $z$ is a vector of human capital variables specific to household $i$ education and morbidity - included as additional factors of production and allowed to neutrally shift this function while all other coefficients are constant. Education is measured as formal schooling received by the household head measured in years while morbidity is measured as the share of household members that had fallen sick during the 12 months preceding the survey. As morbidity and variable inputs - labor and fertilizer - in our case, may be determined simultaneously with output, we use instrumental variables to identify our production function. We subsequently posit a partially linear regression model as proposed by Robinson (1988) and Stock (1989).

$y_{i}=\alpha\left(z_{i}\right)+X_{i} \beta+u_{i}$

In (2) human capital variables - education and morbidity enter the model non parametrically (the functional form of $\alpha(\cdot)$ is not specified). The partially linear model assumes that slope coefficients are invariant to human capital. Human capital variables therefore still only have neutral effects on the production function. Equation (2) can be estimated using Robinson's (1988) double residual estimator

\subsection{Data and Sample}

Data was obtained from the living standards measurement study-integrated surveys on agriculture, general household survey 2015-2016, the national representative survey of 5,000 households, of which 1907 were women representing the geopolitical zones. Consisting of 558 urban and 1349 rural women. The Surveys conducted by the Nigeria' National Bureau of Statistics and the Federal Ministry of Agriculture and Rural Development and the World Bank.

\subsection{Analysis}


Table 1. Correlations Analysis

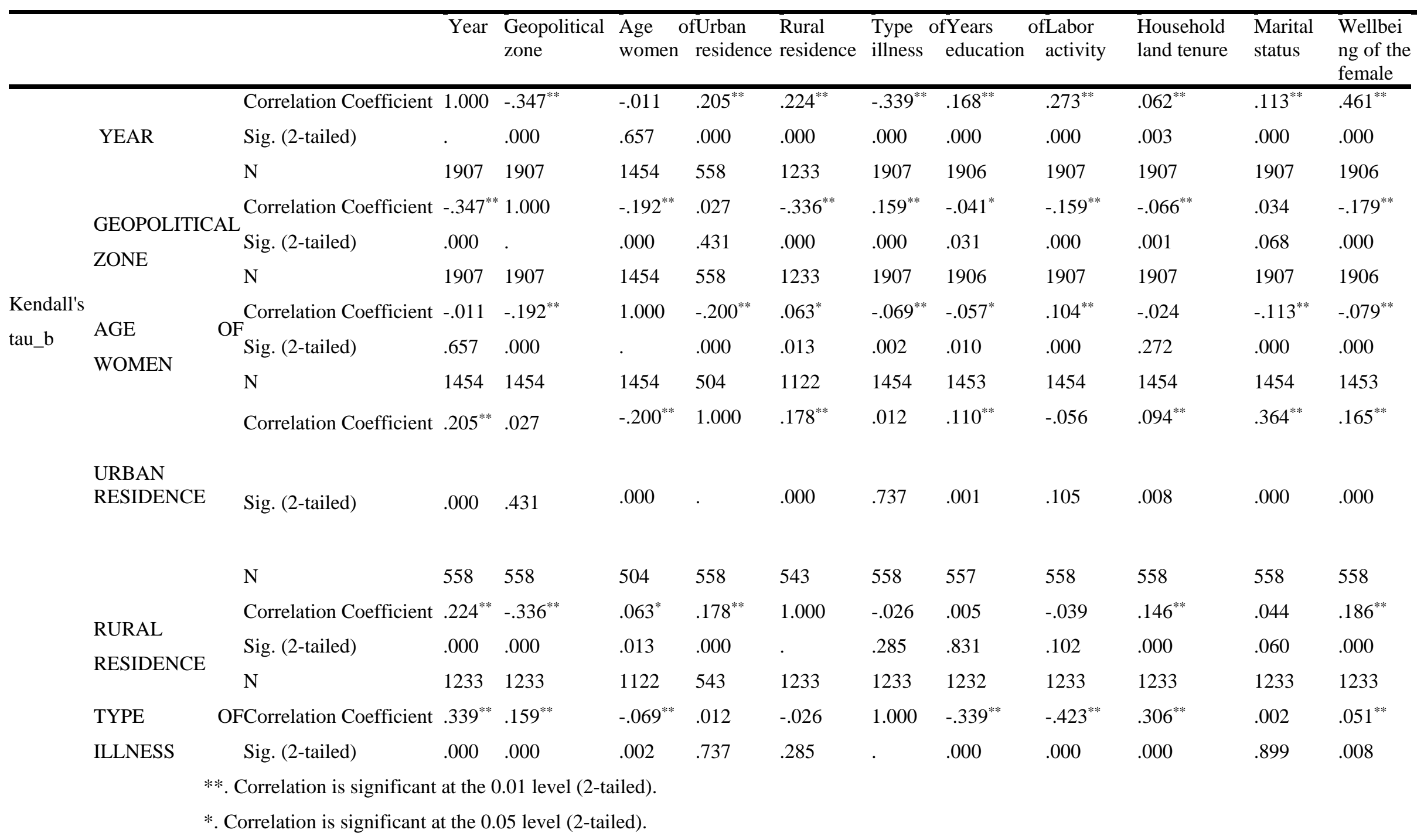


Table 2 above revealed that the year the data was collected is negatively correlated with the geopolitical zone of the women $\mathrm{r}=$ $-.347, \mathrm{p}<.01$, which is significant. Also age of the women is negatively correlated with the year $\mathrm{r}=-.011, \mathrm{p}<.01$, it also significant. The residence of the women urban is positively correlated $\mathrm{r}=.205, \mathrm{p}<.01$, which is also significant. Also rural residence is strongly correlated with the year the data was collected $r=.224, p<.01$, which is also significant. Type of Illness is also negatively correlated with the year $\mathrm{r}=-.339,<.01$. which is also significant. Years of education of the women is positively correlated to the year the data was collected $r=.168, p<.01$, which is also significant. Labor Activity of the women is positively correlated $\mathrm{r}=.273, \mathrm{p}<.01$ which is also significant. Household land tenure is positively correlated $\mathrm{r}=.62, \mathrm{p}<.01$ which is also significant. Marital status is positively correlated $r=.113, p<.01$ which is significant. Wellbeing of the women is positively correlated $\mathrm{r}=.461, \mathrm{p}<.01$ which is significant. Which is consistent with findings by Afridi et al (2011) and Fenske (2011).

Table 2. Model Summary

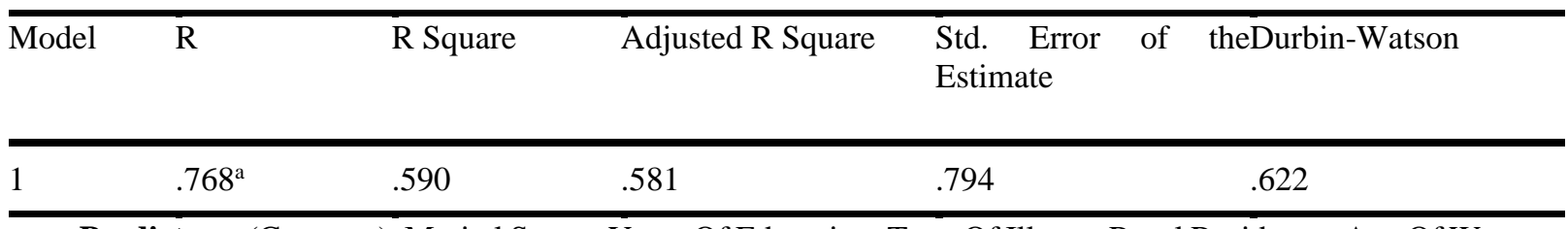

a. Predictors: (Constant), Marital Status, Years Of Education, Type Of Illness, Rural Residence, Age Of Women, Household Land Tenure, Labor Activity, Urban Residence, Year, Geopolitical Zone

b. Dependent Variable: Wellbeing of the female

As shown in table 2 , the $\mathrm{R}^{2}$ is .581 which implies that about 58 percent of the variation in wellbeing of women in Nigeria can be explained by their marital status, years of education, type of illness they have within a given period, place of residence household land tenure and the labor activity they engaged in.

Table 3 ANOVA

\begin{tabular}{llllll} 
Model & Sum of Squares & Df & Mean Square & F & Sig. \\
Regression & 431.987 & 10 & 43.199 & 68.530 & $.000^{\mathrm{b}}$ \\
Residual & 300.683 & 477 & .630 & & \\
Total & 732.670 & 487 & & & \\
\hline
\end{tabular}

a. Dependent Variable: Wellbeing of the Female

b. Predictors: (Constant), Marital Status, Years Of Education, Type Of Illness, Rural Residence, Age Of Women, Household Land Tenure, Labor Activity, Urban Residence, Year, Geopolitical Zone.

Table 4 above revealed that the model is statistically significant. Household, land tenure, type of illness, labor activity and years of education are strongly significant to the wellbeing of women in Nigeria. However type of illness and labor activity reduces the wellbeing of the women, whilst better Household, land tenure and good years of education contribute positively to the well-being of women in Nigeria. Which is consistent to findings by Deininger et al, 2013.

Table 5 showing Coefficients

$\begin{array}{llll}\text { Unstandardized Coefficients } & \text { Beta } & \text { t } & \text { Sig. }\end{array}$

B Std. Error

\begin{tabular}{lllllll}
\hline & (Constant) & -3.681 & .760 & & -4.845 & .000 \\
\multirow{2}{*}{ Equation 1 } & Urban & 1.163 & .314 & 1.124 & 3.699 & .000 \\
& Rural & .429 & .385 & .388 & 1.114 & .266 \\
& Household Land Tenure & -.226 & .466 & -.209 & -.485 & .628 \\
& Labor Activity & 1.359 & .346 & 1.306 & 3.925 & .000 \\
\hline
\end{tabular}

a. Dependent Variable: Wellbeing of the Female 
As shown in table 5 above, Both constant(wellbeing of women) and the household land tenure is negative, which implies that if the land tenure of the women is secured the wellbeing of the women would be better, a positive household land tenure will have a positive wellbeing of the women, that is a one unit increase in Household land tenure will reduce the wellbeing of the women by 2.2 Women in urban areas are worst hit bearing in mind urbanization, which results in the struggle for land among competing uses. The Household land tenure and the Rural Residence are not significant. Rural $=.429, \mathrm{p}=.266$. Household Land tenure $=-.226, \mathrm{p}=.628$. Which implies that wellbeing of women in the urban areas is mostly related to the labor activity they are engaged in, which can be proxy by income, which is a good determinant of poverty.

\section{CONCLUSION}

In conclusion, land tenure type is positively correlated with the wellbeing of the women, also labor activity, years of education and the type of illness are all correlated to the wellbeing of women in Nigeria. They are also significant and good predictors of the wellbeing of women in Nigeria. However labor activity and type of illness negatively affects the wellbeing of women in Nigeria. Which is consistent with findings by Afridi et al (2011); Abdulai et al (2011); Deininger and Feder (2009).

\section{POLICY IMPLICATIONS}

The land use act 1978 should be reviewed and reform to capture the present day reality of vulnerable women. To be able to owned land whether married, single, separated or widowed.

The maternal child health care should be strengthen at the rural area, to provide primary health care to the women, who will in turn be healthy with their children and hence carry out productive farm work. Also, Girl child initiative should be encourage at the rural and urban areas, to encourage women to pursue formal education, which will influence their skills and farming practices

\section{REFERENCES}

[1] Abdulai, A., Owusu, V., and Goetz, R. (2011). Land tenure differences and investment in land improvement measures: Theoretical and empirical analyses. Journal of Development Economics, 96(1), 66-78.

[2] Afridi, F., Mukhopadhyay, A. and Sahoo, S. (2011) 'Female Labour Force Participation and Child Education in India: The Effect of the National Rural
Employment Guarantee Scheme'. IZA Discussion Papers 6593. Institute for the Study of Labor (IZA).

[3] Banerjee, Abhijit, Esther Duflo, Nathanael Goldberg, Dean Karlan, Robert Osei, William Parienté, Jeremy Shapiro, Bram Thuysbaert, and Christopher Udry. (2015). "A Multifaceted Program Causes Lasting Progress for the Very Poor: Evidence from Six Countries." Science 348 (6236): 1260799. doi:10.1126/science. 1260799 .

[4] Benjaminsen, T. A., Holden, S., Lund, C., and Sjaastad, E. (2009) Formalisation of land rights: Some empirical evidence from Mali, Niger, and South Africa. Land Use Policy, 26(1), 28-35.

[5] Besley, T. (1995). Property rights and investment incentives: Theory and evidence from Ghana. Journal of Political Economy, 903-937.

[6] Besley, T., and M. Ghatak. (2010). "Property Rights and Economic Development,"in Rosenzweig, Mark and Dani Rodrik (eds.), Handbook of Development Economics, 5, Oxford and Amsterdam: Elsevier. 4525-4596.

[7] Brasselle, A.-S., Gaspart, F., and Platteau, J.-P. (2002). Land tenure security and investment incentives: puzzling evidence from Burkina Faso. Journal of Development Economics, 67(2), 373-418.

[8] Deininger, K., and Feder, G. (2009). Land registration, governance, and development: Evidence and implications for policy. The World Bank Research Observer, $1 \mathrm{kp} 007$.

[9] Deininger, K. and Jin S. 2006. "Tenure Security and Land-Related Investment: Evidence from Ethiopia," European Economic Review 50 (5): $1245-1277$

[10] Feder, G., and Feeny, D. (1991). Land tenure and property rights: Theory and implications for development policy. The World Bank Economic Review, 5(1), 135-153.

[11] Fenske, J. (2011). Land tenure and investment incentives: Evidence from West Africa. Journal of Development Economics, 95(2), 137-156

[12] Place, F. (2009). Land tenure and agricultural productivity in Africa: a comparative analysis of the economics literature and recent policy strategies and reforms. World Development, 37(8), 1326-1336.

[13] Lastarria-Cornhiel, Julia B., Ruth M., and Agnes Q. 2011."Gender Equity and Land: Toward Secure and Effective Access for Rural Women," Food and Agriculture Organization Background Paper, Rome, Italy: FAO.

\section{AUTHORS}

First Author - Abdulazeez Hakeem Omilola, Phone: +2348059448546, Email: abdulzeezh4@yahoo.com, Department of Estate Management and Valuation, Waziri Umaru Federal Polytechnic, Birnin-Kebbi, Nigeria.

Second Author - Abdulfatai Salawu Oyebode, Phone: +2348035869151 , Department of Estate Management and Valuation, Hussaini Adamu Federal Polytechnic, Kazaure, Nigeria.

Third Author - David Ayock Ishaya, Phone: +2348039681628, Department of Estate Management and Valuation, Hussaini Adamu Federal Polytechnic, Kazaure, Nigeria. 